\title{
Variability in yield of four grain legume species in a subhumid temperate environment. II. Yield components
}

\author{
S. AYAZ, B. A. McKENZIE, G. D. HILL*AND D. L. MCNEIL† \\ Plant Sciences Group, Soil, Plant and Ecological Sciences Division, P.O. Box 84, Lincoln University, Canterbury, \\ New Zealand \\ (Revised MS received 5 January 2004)
}

\begin{abstract}
SUMMARY
The effects of plant population (one-tenth of the optimum to four times the optimum populations in $1998 / 99$ and $10-400$ plants $/ \mathrm{m}^{2}$ in 1999/2000) and sowing depth $(2,5$ and $10 \mathrm{~cm})$ on yield and yield components of four grain-legumes (Cicer arietinum, Lens culinaris, Lupinus angustifolius and Pisum sativum) were studied. Seed yields were strongly positively correlated with the number of pods and seeds $/ \mathrm{m}^{2}$ in both years in all species. The mean seed weight and number of branches/plant were inversely related to plant population. There was a nearly six-fold reduction in the number of branches/plant as plant population increased, which was due to restricted branching, and not to branch senescence. Generally, the variation in yield components was species dependent. However, for all species the number of pods $/ \mathrm{m}^{2}$ and seeds $/ \mathrm{m}^{2}$ could be used as primary criteria for selection in a breeding programme.
\end{abstract}

\section{INTRODUCTION}

Yield variability in grain legumes is mainly correlated with changes in seed number (Moot 1993). However, variations in individual seed weight account for differences in yield among environments within a species, as well as among species in the same environment (Munier-Jolain \& Ney 1998).

The seed yield of grain legumes is the result of many plant growth processes, which are ultimately expressed in the yield components of pods/plant, seeds/pod and mean seed weight. The highest seed yields are generally obtained when all are maximized (Ayaz 2001). The components of yield approach has been used extensively to explain variations in the yield of grain legumes such as Vicia faba (Husain et al. 1988), Phaseolus vulgaris (Dapaah et al. 2000), chickpeas (Verghis 1996) and peas (Nichols et al. 1985).

Yield components can be affected by management, genotype and environment, and may help to explain why a reduction in yield has occurred (Gardner et al. 1985). Management practices to improve each yield

* To whom all correspondence should be addressed. Email: Hill1@lincoln.ac.nz

$\dagger$ DNRE, Victorian Institute for Dryland Agriculture, PMB 260, Horsham Victoria 3401, Australia. component aim to maximize the total seed yield of grain legume crops. However, interdependent compensatory mechanisms among yield components can create a degree of 'plasticity' (Wilson 1987) with the result that even large changes of one yield component may not affect total seed yield (Taweekul 1999).

Considerable work on the influence of plant population density on yield components of grain legumes has been conducted in New Zealand and elsewhere in the world. Varying results have been reported for the optimum plant population and spatial arrangement. The variation in yield components is attributed to differences in soil type, climate, species, time of sowing, fertility and sowing depth. The optimum plant population appears to vary depending on the environmental conditions, plant type and species. However, many workers have described two types of relationships between seed yield and plant population. These forms are asymptotic and parabolic (Moot \& McNeil 1995).

Grantz \& Hall (1982) reported in Vigna unguiculata that large numbers of pods/unit area at low plant populations were mainly due to the high number of pods/branch. Hernandez \& Hill (1983) also reported that the number of pods/plant of chickpea declined with increased plant population and ranged from 23 pods/plant at 33 plants $/ \mathrm{m}^{2}$ to 7 pods/plant at 133 plants $/ \mathrm{m}^{2}$. 
Table 1. Number of plants $/ \mathrm{m}^{2}$ sown and surviving by final harvest in 1998/99 and 1999/2000

\begin{tabular}{|c|c|c|c|c|c|c|c|c|}
\hline \multirow[b]{3}{*}{ Population } & \multicolumn{8}{|c|}{ Species } \\
\hline & \multicolumn{2}{|c|}{ Chickpea } & \multicolumn{2}{|c|}{ Lentil } & \multicolumn{2}{|c|}{ Lupin } & \multicolumn{2}{|c|}{ Pea } \\
\hline & Sown & $\begin{array}{c}\text { At } \\
\text { harvest }\end{array}$ & Sown & $\begin{array}{c}\text { At } \\
\text { harvest }\end{array}$ & Sown & $\begin{array}{c}\text { At } \\
\text { harvest }\end{array}$ & Sown & $\begin{array}{c}\text { At } \\
\text { harvest }\end{array}$ \\
\hline \multicolumn{9}{|l|}{ 1998/99 } \\
\hline $0.1 \times$ optimum & 5 & 5 & 15 & 10 & 10 & 10 & 10 & 10 \\
\hline $1.0 \times$ optimum & 50 & 55 & 150 & 172 & 100 & 97 & 100 & 121 \\
\hline $2.0 \times$ optimum & 100 & 87 & 300 & 312 & 200 & 184 & 200 & 248 \\
\hline $4.0 \times$ optimum & 200 & 149 & 600 & 520 & 400 & 377 & 400 & 329 \\
\hline S.E. $($ D.F. $=24)$ & \multicolumn{8}{|c|}{$5 \cdot 3$} \\
\hline \multicolumn{9}{|l|}{$1999 / 2000$} \\
\hline 10 plants $/ \mathrm{m}^{2}$ & 10 & 10 & 10 & 9 & 10 & 10 & 10 & 8 \\
\hline 100 plants $/ \mathrm{m}^{2}$ & 100 & 98 & 100 & 99 & 100 & 91 & 100 & 95 \\
\hline 400 plants $/ \mathrm{m}^{2}$ & 400 & 394 & 400 & 394 & 400 & 391 & 400 & 395 \\
\hline S.E. $($ D.F. $=16)$ & \multicolumn{8}{|c|}{$2 \cdot 4$} \\
\hline
\end{tabular}

Table 2. Main factor effects for yield components of four grain legume species sown at four plant populations in Canterbury, 1998/99

\begin{tabular}{|c|c|c|c|c|c|}
\hline & Pods/plant & Pods $/ \mathrm{m}^{2}$ & Seeds/pod & Seeds $/ \mathrm{m}^{2}$ & MSWT (mg)* \\
\hline \multicolumn{6}{|l|}{ Species } \\
\hline Chickpea & 101 & 4313 & $1 \cdot 4$ & 5829 & 206 \\
\hline Lentil & 42 & 5549 & $1 \cdot 3$ & 6699 & 52 \\
\hline Lupin & 19 & 1036 & $4 \cdot 3$ & 4358 & 172 \\
\hline Pea & 9 & 633 & $5 \cdot 1$ & 3157 & 159 \\
\hline S.E. (D.F. $=6)$ & $1 \cdot 1$ & $126 \cdot 0$ & $0 \cdot 04$ & $331 \cdot 0$ & $3 \cdot 6$ \\
\hline \multicolumn{6}{|l|}{ Population } \\
\hline $0 \cdot 1 \times$ optimum & 98 & 715 & $3 \cdot 3$ & 1746 & 155 \\
\hline $1.0 \times$ optimum & 35 & 3116 & $3 \cdot 1$ & 5578 & 152 \\
\hline $2 \cdot 0 \times$ optimum & 24 & 3580 & $2 \cdot 9$ & 6142 & 145 \\
\hline $4.0 \times$ optimum & 14 & 4119 & $2 \cdot 7$ & 6578 & 137 \\
\hline S.E. (D.F. $=24)$ & $4 \cdot 5$ & $116 \cdot 2$ & $0 \cdot 10$ & $361 \cdot 0$ & $1 \cdot 5$ \\
\hline $\mathrm{CV} \%$ & $5 \cdot 1$ & $13 \cdot 9$ & $10 \cdot 60$ & $23 \cdot 9$ & $2 \cdot 4$ \\
\hline
\end{tabular}

* Mean seed weight.

The number of pods/plant is the most important component in determining the yield of several legume crops such as pea (Pandey \& Gritton 1975) and chickpea (Siddique \& Sedgley 1986). Generally, variation in the number of pods/plant depends on species. However, the number of pods/plant produced, or maintained to final harvest, depends on environmental conditions and management practices (Knott 1987). The aim of the present study was to test the contribution of yield components and their determinants to variation in the yield of four grain legume species sown at different plant populations and sowing depths in the subhumid temperate environment of Canterbury, New Zealand.

\section{MATERIALS AND METHODS}

Soil characteristics, experimental design, species, crop husbandry, plant sampling, standard measurements, procedures and climate are described in full in Ayaz et al. (2004). Briefly, in 1998/99, the design was a split plot with four legume species: chickpea (Cicer arietinum), lentils (Lens culinaris), narrow-leafed lupin (Lupinus angustifolius) and field pea (Pisum sativum) as the main plots. Subplots were four plant populations: one-tenth of the optimum, the optimum, twice the optimum or four times the optimum populations. The optimum populations for chickpea, lentils, lupin and pea were $50,150,100$ or 100 plants $/ \mathrm{m}^{2}$, respectively. 
Table 3. Main factor effects for yield components of four grain legume species sown at three plant populations and three sowing depths in Canterbury, 1999/2000

\begin{tabular}{|c|c|c|c|c|c|c|}
\hline & Branches/plant & Pods/plant & Pods $/ \mathrm{m}^{2}$ & Seeds/pod & Seeds $/ \mathrm{m}^{2}$ & MSW (mg)* \\
\hline \multicolumn{7}{|l|}{ Species } \\
\hline Chickpea & 20 & 52 & 3086 & $1 \cdot 3$ & 3801 & 141 \\
\hline Lentil & 31 & 67 & 4085 & $1 \cdot 4$ & 5200 & 56 \\
\hline Lupin & 15 & 23 & 967 & $4 \cdot 2$ & 3817 & 132 \\
\hline Pea & 12 & 13 & 683 & $5 \cdot 2$ & 3363 & 106 \\
\hline S.E. $($ D.F. $=6)$ & $0 \cdot 5$ & $1 \cdot 8$ & $51 \cdot 6$ & $0 \cdot 17$ & $153 \cdot 6$ & $6 \cdot 7$ \\
\hline \multicolumn{7}{|l|}{ Population } \\
\hline 10 plants $/ \mathrm{m}^{2}$ & $38 \cdot 3$ & 87 & 912 & $3 \cdot 3$ & 2098 & 118 \\
\hline 100 plants $/ \mathrm{m}^{2}$ & $14 \cdot 2$ & 19 & 1879 & $3 \cdot 1$ & 3826 & 112 \\
\hline 400 plants $/ \mathrm{m}^{2}$ & $5 \cdot 8$ & 10 & 3825 & $2 \cdot 6$ & 6212 & 96 \\
\hline S.E. (D.F. = 16) & $0 \cdot 39$ & $1 \cdot 6$ & $87 \cdot 2$ & $0 \cdot 06$ & $142 \cdot 4$ & $2 \cdot 5$ \\
\hline \multicolumn{7}{|l|}{ Depth (cm) } \\
\hline $2 \mathrm{~cm}$ & $19 \cdot 3$ & 37 & 2051 & $3 \cdot 1$ & 3808 & 114 \\
\hline $5 \mathrm{~cm}$ & $19 \cdot 5$ & 39 & 2235 & $3 \cdot 0$ & 4177 & 107 \\
\hline $10 \mathrm{~cm}$ & $19 \cdot 4$ & 40 & 2329 & $2 \cdot 9$ & 4151 & 106 \\
\hline S.E. (D.F. $=48)$ & $0 \cdot 16$ & $0 \cdot 23$ & $46 \cdot 1$ & $0 \cdot 02$ & $78 \cdot 7$ & $1 \cdot 5$ \\
\hline CV \% & $4 \cdot 9$ & $3 \cdot 5$ & $12 \cdot 6$ & $3 \cdot 8$ & $11 \cdot 7$ & $8 \cdot 2$ \\
\hline
\end{tabular}

* Mean seed weight.

In $1999 / 2000$, the experiment was a split split-plot design with the same four legume species as main plots. The subplots were three plant populations of 10,100 or 400 plants $/ \mathrm{m}^{2}$ and the sub-subplots were three sowing depths $(2,5$ or $10 \mathrm{~cm})$. The first experiment was given $75 \mathrm{~mm}$ of water by sprinkler irrigation during the growing season but no irrigation was applied to the second.

In the first season, sowing was done using a tractordriven cone seeder. In the second trial seed was hand sown. Holes were made with dibbers; seed was placed at the bottom of the hole and the surface firmed. Seed was sown at an accurate depth and precisely on the squares to obtain the target populations.

All variates were analysed using analysis of variance procedures with the statistical programme Genstat (Genstat 5 Committee of the Statistics Department, Rothamsted Experimental Station, Hertfordshire, UK).

\section{RESULTS \\ Plants $/ m^{2}$}

In 1998/99, the higher plant populations were generally lower than the target populations and in the following season, all targeted populations were achieved (Table 1).

\section{Pods/plant}

The number of pods/plant varied over a greater range than all the other yield components and depended on
Table 4. The species by sowing depth interaction for pods/plant in Canterbury, 1999/2000

\begin{tabular}{lccc}
\hline \hline & \multicolumn{3}{c}{ Sowing depth (cm) } \\
\cline { 2 - 4 } Species & 2 & 5 & 10 \\
\hline Chickpea & 49 & 53 & 54 \\
Lentil & 66 & 67 & 69 \\
Lupin & 22 & 23 & 24 \\
Pea & 12 & 13 & 14 \\
S.E. (D.F.=48) & & $1 \cdot 89$ & \\
\hline \hline
\end{tabular}

both legume species and population (Tables 2 and 3). The species $\times$ population interactions were highly significant $(P<0 \cdot 001)$ in both seasons (Fig. $1 a, b)$ and the number of pods/plant decreased with increased plant population. However, the number of pods $/ \mathrm{m}^{2}$ increased as plant population increased (Tables 2 and 3 ) which made a significant contribution to yield in both seasons (Fig. $2 a, b$ ).

Chickpea produced the most pods/plant (221) in $1998 / 99$ and lentils (146 pods/plant) in 1999/2000 (Fig. 1 $a, b$ ). In 1999/2000, the species $\times$ sowing depth interaction (Table 4) showed that deeper sowing significantly $(P=0.05)$ increased the number of pods/ plant in all species. In both seasons the number of pods $/ \mathrm{m}^{2}$ made a major contribution to crop yield.

Yield and crop harvest index (CHI) were inversely related to pods/plant but were positively and significantly correlated with pods $/ \mathrm{m}^{2}$ (Table 5). 

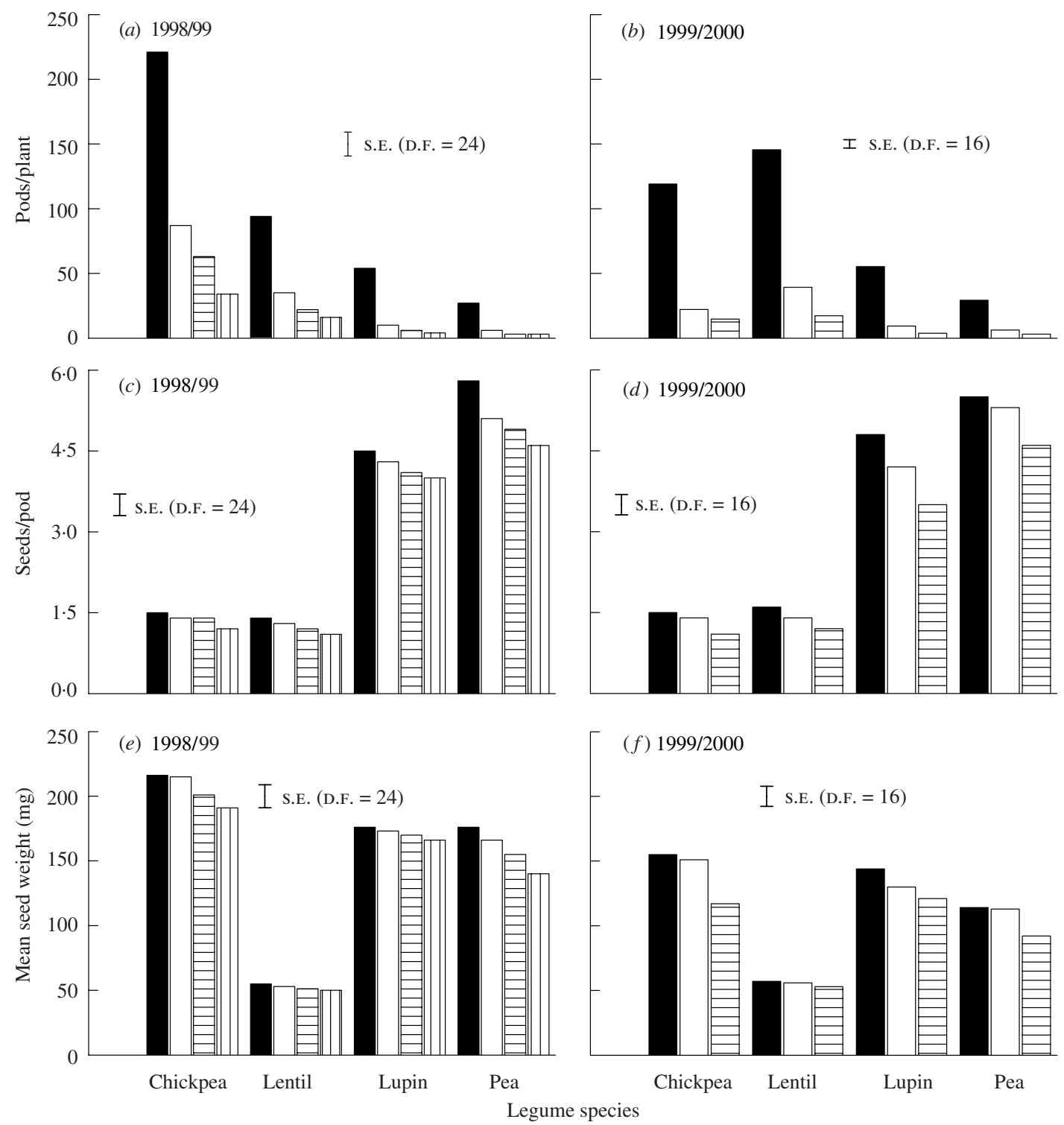

Fig. 1. The interaction between legume species and plant population on yield components in Canterbury, 1998/99 (a,c,e); one-tenth of the optimum population ( $\square)$, the optimum population $(\square)$, twice the optimum population (E), four times the optimum population (II) and 1999/2000 $(b, d, f) ; 10$ plants $/ \mathrm{m}^{2}(\boldsymbol{\square}), 100 \mathrm{plants} / \mathrm{m}^{2}(\square), 400 \mathrm{plants} / \mathrm{m}^{2}$ (巨E).

\section{Seeds/pod}

The average number of seeds in each pod was inversely related to plant population. However, as plant population increased so did the number of seeds $/ \mathrm{m}^{2}$ (Tables 2 and 3) in both seasons. Seed yield and CHI were positively correlated with seeds $/ \mathrm{m}^{2}$ but were negatively correlated with seeds/pod. Field peas had more seeds/pod than the other three species at all populations in both years (chickpea 1.4 and 1.3 ; lentil 1.3 and 1.4 ; narrow-leafed lupin 4.3 and $4 \cdot 2$; pea $5 \cdot 1$ and $5 \cdot 2$ seeds/pod, in 1998/99 and 1999/2000, respectively). The number of seeds/pod decreased as plant population increased from one-tenth of the optimum to four times the optimum (Fig. $1 c, d$ ), but plants sown at the higher populations compensated by having more seeds $/ \mathrm{m}^{2}$ (Fig. $2 c, d$ ). 

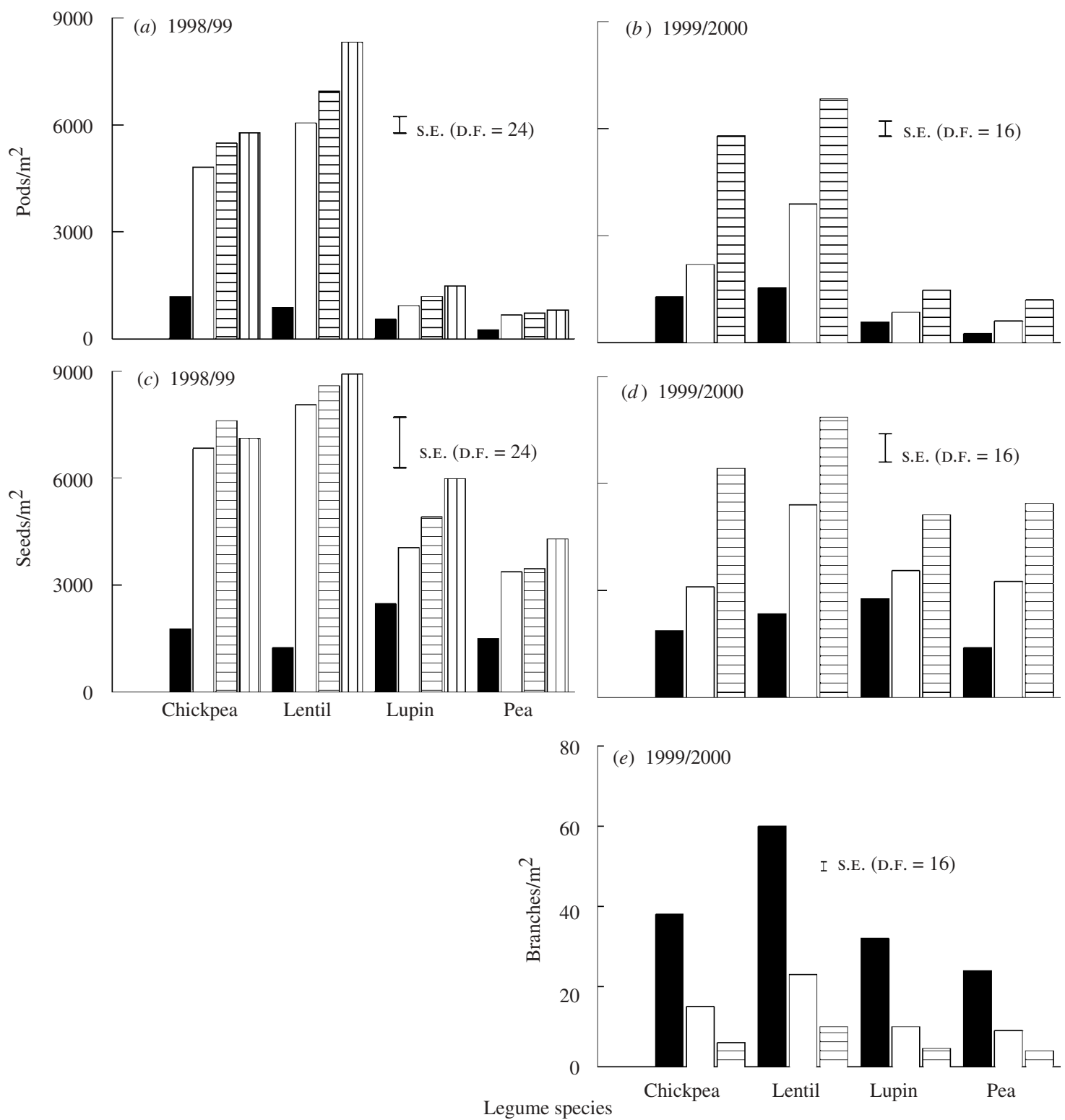

Fig. 2. The interaction between legume species and plant population on yield components and branch number in Canterbury, 1998/99 (a,c); one-tenth of the optimum population $(\boldsymbol{\square})$, the optimum population $(\square)$, twice the optimum population (E), four times the optimum population (III) and $1999 / 2000(b, d, e) ; 10$ plants $/ \mathrm{m}^{2}(\boldsymbol{\square}), 100$ plants $/ \mathrm{m}^{2}(\square), 400 \mathrm{plants} / \mathrm{m}^{2}($ E).

\section{Mean seed weight}

Averaged over all populations the mean seed weight (206 and $141 \mathrm{mg}$ ) of chickpea was higher than in the other three species (Tables 2 and 3) in both 1998/99 and $1999 / 2000$. There was a trend in all four species for the mean seed weight to decrease as plant population increased (Fig. 1e,f). The significant interaction
$(P<0.05)$ between species and plant population showed that in both seasons the mean seed weight of some of the species, e.g. chickpea and field pea, was strongly influenced by plant population. However, plant population did not affect lentil mean seed weight and lupin was affected by increased population less than pea and chickpea, especially in the first season. 
Table 5. The correlation matrix between seed yield and its components in four grain legume species grown in Canterbury, 1998/99 and 1999/2000

\begin{tabular}{|c|c|c|c|c|c|c|c|}
\hline Species & Year & Pods/plant & Pods $/ \mathrm{m}^{2}$ & Seeds/pod & Seeds $/ \mathrm{m}^{2}$ & MSWT & $\begin{array}{c}\text { Branches/ } \\
\text { plant }\end{array}$ \\
\hline \multirow[t]{2}{*}{ Chickpea } & 1998/99 & -0.944 & 0.942 & -0.497 & 0.898 & -0.688 & - \\
\hline & $1999 / 00$ & -0.882 & $0 \cdot 863$ & -0.607 & 0.933 & -0.448 & -0.967 \\
\hline \multirow{2}{*}{ Lentil } & 1998/99 & -0.954 & $0 \cdot 950$ & $-0 \cdot 467$ & 0.980 & -0.724 & - \\
\hline & $1999 / 00$ & -0.970 & 0.968 & -0.635 & 0.898 & -0.444 & -0.982 \\
\hline \multirow[t]{2}{*}{ Lupin } & 1998/99 & $-0 \cdot 881$ & 0.793 & -0.767 & $0 \cdot 744$ & $-0 \cdot 512$ & - \\
\hline & $1999 / 00$ & -0.873 & 0.954 & -0.763 & 0.937 & -0.401 & -0.913 \\
\hline \multirow[t]{2}{*}{ Pea } & $1998 / 99$ & -0.977 & 0.832 & -0.677 & $0 \cdot 718$ & -0.570 & - \\
\hline & $1999 / 00$ & -0.938 & $0 \cdot 885$ & $-0 \cdot 511$ & $0 \cdot 887$ & $-0 \cdot 301$ & -0.963 \\
\hline
\end{tabular}

All values are significant at $P<0.001$.

\section{Branches/plant}

The number of branches/plant was strongly influenced by plant population and species (Table 3). Lentils produced the most branches at 31 branches/ plant, while peas produced the least at 12 branches/ plant. Increasing plant population from 100 to 400 plants $/ \mathrm{m}^{2}$ decreased branch number/plant six-fold in each species (Fig. 2e).

\section{Yield and yield components relationships}

The simple correlations summarized for all four species in Table 5 showed that the numbers of pods/ plant, seeds/pod, branches/plant and the mean seed weight were negatively correlated with seed yield in all four species. However, seed yield was positively and strongly correlated with both pods and seeds $/ \mathrm{m}^{2}$.

\section{DISCUSSION}

Averaged over all populations, chickpea produced the most pods/plant in 1998/99 and lentils in 1999/ 2000. Severe competition at 600 plants $/ \mathrm{m}^{2}$ in lentil in the first trial and in chickpeas at 400 plants $/ \mathrm{m}^{2}$ in $1999 / 2000$ greatly decreased the number of pods/ plant. The main source of low and variable number of pods/plant was inter-plant competition (Moot \& McNeil 1995; Palta \& Ludwig 1998). The reduction in pods/plant at the higher populations was primarily due to the restricted branching. Since pod development occurs on branches, reducing the number of branches by sowing at high populations reduces the number of possible sites for pods/plant (McKenzie et al. 1986; Dracup \& Thomson 2000). Moot \& McNeil (1995) and Milford et al. (1999) working with peas and Lupinus albus, respectively, reported similar results of decreased pods/plant with increased plant population. In 1999/2000, increasing sowing depth also increased pods/plant. This increase may have been due to more moisture at the $10 \mathrm{~cm}$ depth. Siddique \& Loss (1999) also reported that the availability of more moisture in the subsoil resulted in an increase in the number of pods/plant.

Many workers have found that the number of pods/plant was inversely related to plant population (Hernandez \& Hill 1983; McKenzie \& Hill 1995). However, the number of pods $/ \mathrm{m}^{2}$ increased as plant population increased. In the present work, seed yields were negatively correlated with pods/plant but correlated with pods $/ \mathrm{m}^{2}$ in both years in all species. Similar relationships have been reported in a range of grain legumes (Husain et al. 1988; Loss \& Siddique 1997). Yield variation was associated with significant variation in pods $/ \mathrm{m}^{2}$. This yield component could therefore possibly be used as a primary criterion for selection at a late stage of a breeding programme.

In both years, the number of seeds/pod were greatest in all species, when they were sown at a low population; the number of seeds/pod decreased with increased plant density. This was consistent with the results of other workers on pea (Moot 1993), lentil (McKenzie et al. 1986) and field bean (Vicia faba) (Attiya et al. 1983). The significant species $\times$ populapopulation interaction indicated that field pea consistently produced more seeds/pod over all plant populations and in both seasons than the other three species. In chickpea and lentil, at all populations, in both years, there was a similar number of seeds/pod but the seed yield was significantly different between these two species. In contrast, at all populations, narrow-leafed lupin produced fewer seeds/pod than field pea, but had a significantly higher seed yield. Moot \& McNeil (1995) found similar contradictions among pea genotypes.

Since seed size is the most stable yield component, the number of seeds/unit area is likely to be the most important contributor to seed yield. Improvements in the seed yield potential of grain legumes can be 
obtained from higher biomass production which produces more pods $/ \mathrm{m}^{2}$, slightly higher mean seed weights, and hence higher yields. In the present study, variation in seeds $/ \mathrm{m}^{2}$ contributed more to variation in seed yield than either seeds/pod or mean seed weight (Ayaz et al. 2004). Therefore, seeds/unit area may also be a good selection criterion (D. L. McNeil \& D. J. Moot, personal communication).

Mean seed weight was inversely correlated with the seed yield. Plant population changes influenced the mean seed weight. In 1998/99, seed yield of the narrow-leafed lupin was highest at one-tenth of the optimum plant population but better yields were achieved with chickpeas grown at the optimum to four times the optimum plant population. In 1999/ 2000, narrow-leafed lupin at 10 and 100 plants $/ \mathrm{m}^{2}$ was superior to chickpea but at 400 plants $/ \mathrm{m}^{2}$ both species had similar seed yields (Ayaz et al. 2004).

These results suggest that mean seed size is not an important determinant of seed yield. Similar findings in pea genotypes were reported by Moot \& McNeil (1995), who concluded that mean seed weight would not be a reliable character to use to select for improved yield due to its instability.

Branching was suppressed at high plant populations in all four species and was reduced by more than $50 \%$ as population increased from 10 to 400 plants/ $\mathrm{m}^{2}$ in chickpea and lentil (Hernandez 1986; Effendi et al. 1989). In the present study, the number of branches/plant decreased nearly six-fold as the plant population increased from 10 to 400 plants $/ \mathrm{m}^{2}$. This indicates that inter-plant competition was intense at the higher plant populations and that there were severe limitations in environmental resources available to individual plants (Hernandez 1986). The high number of branches/plant at the low population was probably due to the low density allowing more radiation to penetrate the crop canopy. Generally, responsiveness to increased plant population was similar in all four species. Similar results were reported for Lupinus angustifolius by Herbert \& Hill (1978) and by Dracup \& Thomson (2000).

In all four species in both seasons, there were highly significant negative correlations between seed yield and number of pods/plant and seeds/pod. Character association among yield components suggested that there was a positive correlation between the number of pods $/ \mathrm{m}^{2}$ and seeds $/ \mathrm{m}^{2}$, which in turn was associated with seed yield. This would serve as a basis for crop selection. The importance of the number of pods $/ \mathrm{m}^{2}$ as a determination of yield in pea has previously been confirmed in Australia (French 1990) and in Canterbury (Moot 1997).

A conclusion of the present study is that the number of pods and seeds $/ \mathrm{m}^{2}$ strongly and positively affected the seed yield. Therefore, improvements in the seed yield potential of grain legumes can be made from increased biomass production, primarily through an increased number of seeds $/ \mathrm{m}^{2}$ via an augmented number of pods $/ \mathrm{m}^{2}$ combined with a higher average seed weight.

Thanks are due to Laila Ayaz for her help with sample collection. Financial support for Shaukat Ayaz by the New Zealand Vice-Chancellors' Committee is acknowledged.

\section{REFERENCES}

Attiya, H. J., Field, R. J. \& Hill, G. D. (1983). Effect of $\mathrm{PP}_{333}$ and TIBA growth regulators on development and yield components of spring sown field beans (Vicia faba L.). Proceedings of the Agronomy Society of New Zealand 13, 81-86.

AyAZ, S. (2001). Variability of harvest index in four grain legume species. Ph.D. thesis, Lincoln University, Canterbury.

Ayaz, S., McKenzie, B. A., Hill, D. G. \& McNeil, D. L. (2004). Variability in yield of four grain legume species in a subhumid temperate environment. I. Yields and harvest index. Journal of Agricultural Science, Cambridge 142, 9-20.

Dapaah, H. K., McKenzie, B. A. \& Hill, G. D. (2000). Influence of sowing date and irrigation on the growth and yield of pinto beans (Phaseolus vulgaris) in a sub-humid temperate environment. Journal of Agricultural Science, Cambridge 134, 33-43.

Dracup, M. \& Thomson, B. (2000). Narrow-leafed lupins with restricted branching. Annals of Botany $\mathbf{8 5}$ 29-35.

EfFendi, H., Hill, G. D. \& Field, R. J. (1989). The effect of plant population and growth regulators on growth and yield of lentil (Lens culinaris Medik.) cv. Olympic. Proceedings of the Agronomy Society of New Zealand 19, 25-34.

French, R. J. (1990). The contribution of pod number to field pea (Pisum sativum L.) yields in a short growing season environment. Australian Journal of Agricultural Research 41, 853-862.

Gardner, F. P., Pearce, R. B. \& Mitchell, R. L. (1985). Physiology of Crop Plants. Ames, IA: Iowa State University Press.

Grantz, D. A. \& Hall, A. E. (1982). Earliness of an indeterminate crop, Vigna unguiculata (L.) Walp., as affected by drought, temperature and plant density. Australian Journal of Agricultural Research 33, 531-540.

Herbert, S. J. \& Hill, G. D. (1978). Plant density and irrigation studies on lupins. I. Growth analysis of Lupinus angustifolius WAU 11B. New Zealand Journal of Agricultural Research 21, 467-474.

Hernandez, L. G. (1986). Study of the agronomy of chickpea (Cicer arietinum L.) in Canterbury. Ph.D. thesis, Lincoln College, University of Canterbury.

Hernandez, L. G. \& Hill, G. D. (1983). Effect of plant population and inoculation on yield and yield components 
of chickpeas (Cicer arietinum). Proceedings of the Agronomy Society of New Zealand 13, 75-79.

Husain, M. M., Hill, G. D. \& Gallagher, J. N. (1988). The response of field beans (Vicia faba L.) to irrigation and sowing date. I. Yield and yield components. Journal of Agricultural Science, Cambridge 111, 221-232.

KnotT, C. M. (1987). A key for stages of development of the pea (Pisum sativum). Annals of Applied Biology 111, 233-245.

Loss, S. P. \& Siddique, K. H. M. (1997). Adaptation of Faba bean (Vicia faba L.) to dryland Mediterranean-type environments. I. Seed yield and yield components. Field Crops Research 52, 17-28.

McKenzie, B. A. \& Hill, G. D. (1995). Growth and yield of two chickpeas (Cicer arietinum L.) varieties in Canterbury, New Zealand. New Zealand Journal of Crop and Horticultural Science 23, 467-474.

McKenzie, B. A., Hill, G. D., White, J. G. H., Meijer, G., Sikken, G., Nieuwenhuyse, A. \& Kausar, A. G. (1986). The effect of sowing date and population on yield of lentils (Lens culinaris Medik). Proceedings of the Agronomy Society of New Zealand 16, 29-33.

Milford, G. F. J., Shield, I. F., Stevenson, H. J., Scott, T. \& LEACH, J. E. (1999). Seed and pod development of autumn-sown, determinate white lupins (Lupinus albus) in relation to the assimilation and distribution of dry matter and nitrogen in crops grown at different densities. Journal of Agricultural Science, Cambridge 133, 141-150.

Mоот, D. J. (1993). Harvest index variability within and between field pea (Pisum sativum L.) crops. Ph.D. thesis, Lincoln University, Canterbury.

Mоот, D. J. (1997). Theoretical analysis of yield of field pea (Pisum sativum L.) crop using frequency distributions for individual plant performance. Annals of Botany 79, 429-437.

Moot, D. J. \& McNeil, D. L. (1995). Yield components, harvest index and plant type in relation to yield differences in field pea genotypes. Euphytica 86, $31-40$.

Munier-Jolain, N. G. \& Ney, B. (1998). Seed growth rate in grain legumes. II. Seed growth rate depends on cotyledon cell number. Journal of Experimental Botany 49, 1971-1976.

Nichols, M. A., Ragan, P. \& Floyd, R. M. (1985). Temperature and plant density studies with vining peas. In The Pea Crop - a Basis for Improvement (Eds P. D. Hebblethwaite, M. C. Heath \& T. C. K Dawkins), pp. 173-184. London: Butterworths.

Palta, J. A. \& Ludwig, C. (1998). Yield response of narrow-leafed lupin plants to variations in pod number. Australian Journal of Agricultural Research 49, 63-68.

Pandey, S. \& Gritton, E. T. (1975). Genotypic and phenotypic variances and correlations in peas. Crop Science $\mathbf{1 5}$, 353-356.

Siddique, K. H. M. \& Loss, S. P. (1999). Studies on sowing depth for chickpea (Cicer arietinum L.), faba bean (Vicia faba L.) and lentil (Lens culinaris Medik), in a Mediterranean-type environment of south-western Australia. Journal of Agronomy and Crop Science 182, $105-112$

Siddique, K. H. M. \& Sedgley, R. H. (1986). Canopy development modifies the water economy of chickpea (Cicer arietinum L.) in south-western Australia. Australian Journal of Agricultural Research 37, 599-610.

TAwEeKul, N. (1999). Factors affecting seed vigour in field peas (Pisum sativum). Ph.D. thesis, Lincoln University, Canterbury.

Verghis, T. I. (1996). Yield and yield development of chickpea (Cicer arietinum L.). Ph.D. thesis, Lincoln University, Canterbury.

WiLSON, D. R. (1987). New approaches to understanding the growth and yield of pea crops. Agronomy Society of New Zealand 6, 23-28. 